Article

\title{
Effects of Adding Alkali Metals and Organic Cations to Cu-Based Perovskite Solar Cells
}

\author{
Riku Okumura ${ }^{1}$, Takeo Oku ${ }^{1, * \mathbb{D}}$, Atsushi Suzuki ${ }^{1} \mathbb{D}$, Masanobu Okita $^{2}$, Sakiko Fukunishi ${ }^{2}$, \\ Tomoharu Tachikawa ${ }^{2}$ and Tomoya Hasegawa ${ }^{2}$
}

1 Department of Materials Science, The University of Shiga Prefecture, 2500 Hassaka, Hikone 522-8533, Shiga, Japan; oe21rokumura@ec.usp.ac.jp (R.O.); suzuki@mat.usp.ac.jp (A.S.)

2 Osaka Gas Chemicals Co., Ltd., 5-11-61 Torishima, Konohana-ku, Osaka 554-0051, Japan; okita@ogc.co.jp (M.O.); fukunishi@ogc.co.jp (S.F.); t-tachikawa@ogc.co.jp (T.T.); hasegawa_tomoya@ogc.co.jp (T.H.)

* Correspondence: oku@mat.usp.ac.jp; Tel.: +81-749-28-8368

check for updates

Citation: Okumura, R.; Oku, T.; Suzuki, A.; Okita, M.; Fukunishi, S.; Tachikawa, T.; Hasegawa, T. Effects of Adding Alkali Metals and Organic Cations to $\mathrm{Cu}$-Based Perovskite Solar Cells. Appl. Sci. 2022, 12, 1710. https://doi.org/10.3390/app12031710 Academic Editor: Nobuya Sakai

Received: 20 December 2021 Accepted: 3 February 2022 Published: 7 February 2022 Publisher's Note: MDPI stays neutral with regard to jurisdictional claims in published maps and institutional affiliations.

Copyright: (C) 2022 by the authors. Licensee MDPI, Basel, Switzerland. This article is an open access article distributed under the terms and conditions of the Creative Commons Attribution (CC BY) license (https:// creativecommons.org/licenses/by/ $4.0 /)$.

\begin{abstract}
First-principles electronic band calculations were used to investigate the effects of alkali metals and organic cations added to $\mathrm{Cu}$-based perovskite solar cells. The copper d-orbital band was slightly above the valence-band maximum and functioned as an acceptor level for carrier generation. Excitation from iodine p-orbitals and copper d-orbitals to alkali metal s-orbitals could suppress carrier recombination and promote carrier transport. Experimental solar conversion efficiencies increased after adding both $\mathrm{Cu}$ and $\mathrm{Na}$, in agreement with the calculations. Total-energy calculations indicated that the perovskite crystal stability increased with the addition of ethyl ammonium, although the total energy decreased with the addition of $\mathrm{Cu}$ and $\mathrm{Na}$.
\end{abstract}

Keywords: copper; sodium; ethylammonium; first-principles calculations; perovskite; solar cell

\section{Introduction}

There have been many efforts to improve the conversion efficiencies and durabilities of perovskite photovoltaic devices by adding metal, halogen, and organic ions to the precursor solutions [1-3]. Other approaches have included the development of scalable processes via electrodeposition [4,5], stable fully inorganic perovskites [6], polymer composites using perovskites [7], and solvent effects in the precursor solution on perovskite film microstructures [8].

Here, additives such as copper $(\mathrm{Cu})$, sodium $(\mathrm{Na})$, and ethyl ammonium (EA) were examined. $\mathrm{Cu}$ compounds such as copper thiocyanate $(\mathrm{CuSCN})$, copper oxides, $\left(\mathrm{Cu}_{\mathrm{x}} \mathrm{O}\right)$, and copper iodide, were mainly used as hole-transport materials that replaced organic versions [9-14]. Although there have been many reports on the addition of alkali metals to perovskite precursor solutions [15-23], relatively few reported on the addition of $\mathrm{Cu}$ [24-27]. The addition of $\mathrm{CuBr}_{2}$ and $\mathrm{NaCl}$ to the solutions improved the solar conversion efficiency and device durability [28-30]. In those studies, lattice distortion in the perovskite crystals was reduced by small amounts of $\mathrm{Cu}$, and lattice defects were suppressed with $\mathrm{Na}$ at the defect sites after desorption of methylammonium (MA), which improved conversion efficiency and device durability.

First-principles calculations of perovskite crystals have been performed using structural models in which organic cations, metal cations, and halogen anions were replaced with other groups to examine the crystal structure stability. $\mathrm{CH}_{3} \mathrm{NH}_{3} \mathrm{PbI}_{3}\left(\mathrm{MAPbI}_{3}\right)$ is the standard perovskite compound used for photoelectric conversion [31]. Previously, calculations indicated that EA substitution for MA enhanced the structural stability [32], and the calculated energy gap agreed well with experimental values [33]. The addition of other organic cations and combinations of multiple organic cations have also been studied. The introduction of EA and butyl-ammonium affected the conduction-band minima, 
valence-band maxima, and the surface morphologies of MA-based perovskites [34]. Increased coulomb interactions between cations, attributed to the additional organic cations, enhanced the perovskite stability and device durability. There have been other reports on using larger organic cations to replace MA and improve device properties [35-39].

The effects of halogen additions have been examined computationally and experimentally [40-43]. A Br-rich sample resulted in larger grain sizes and fewer grain boundaries because of the reduced number of nucleation sites during perovskite crystal growth [44]. Defects distributed at grain boundaries were thus reduced by fewer boundaries, which increased carrier lifetimes. Br-rich samples exhibited higher thermal and optical stabilities relative to $\mathrm{MAPbI}_{3}$ devices. It is expected that perovskite film quality and stability could be improved via halogen selectivity. The replacement of I with $\mathrm{Br}$ or $\mathrm{Cl}$ changed the band gap and charge-transfer properties. Monovalent pseudo-halogens, such as thiocyanate, have properties like those of halogens, they could improve photoelectric conversion and stability, and may prevent oxidation of $\mathrm{Sn}^{2+}$ to $\mathrm{Sn}^{4+}$ in Sn-based perovskites [45]. The latter was expected to suppress oxidation-induced degradation. The thiocyanate ions also increased the grain size and improved the surface morphology and crystallinity, which increased photoelectric conversion and stability. Thus, the $\mathrm{Pb}, \mathrm{MA}$, and halogen sites are very important because the perovskite energy gap and crystallinity change with added materials.

Here, the effects of adding $\mathrm{Cu}, \mathrm{Na}$, and EA to the perovskite precursor solution were investigated with first-principles calculations. The addition of $2 \% \mathrm{Cu}$ and $2 \% \mathrm{Na}$ to $\mathrm{MAPbI}_{3}$ improved the photoelectric conversion efficiency [29]. Therefore, increased conversion properties and device durability by adding EA, together with 2-\% $\mathrm{Cu}$ and 2-\% $\mathrm{Na}$, were examined. The calculations were performed to understand the doping effects in more detail, and to compare them with experimental results. Both total- and partial-substitution structure models approximating perovskite compositions in actual devices were used to investigate the effects.

\section{Computational Conditions and Experimental Methods}

The electronic structures of the perovskite crystals were single-point-calculated with crystallographic structural data obtained from X-ray diffraction. The ab initio quantum calculations were performed using the Vanderbilt ultrasoft pseudo-potentials, scalar relativistic generalized gradient approximations and the Perdew-Burke-Ernzerhof exchange correlation functional and density functional theory without consideration of spin-orbital coupling effect (Quantum Espresso Software Ver. 5. 2. 1, Quantum ESPRESSO Foundation, Cambridge, UK). The basis functions were used properly according to the cases of itinerant and localized electron system. Plane-wave basis set cut offs for the wave functions and charge density were set at 25 and 225 Rydberg. The perovskite crystals were constructed with a crystal system of $P \bar{m} 3 \bar{m}$. Uniform $k$-point grid $(4 \times 4 \times 4)$ in the Brillouin zone was used to calculate the electronic structure and partial density of state. The $\mathrm{ABX}_{3}$ $\left(\mathrm{A}=\mathrm{Na}^{+}, \mathrm{K}^{+}, \mathrm{Rb}^{+}, \mathrm{Cs}^{+}, \mathrm{MA}^{+}\right.$, or $\mathrm{EA}^{+}, \mathrm{B}=\mathrm{Pb}^{2+}$ or $\mathrm{Cu}^{2+}, \mathrm{X}=\mathrm{I}^{-}, \mathrm{Br}^{-}$, or $\mathrm{Cl}^{-}$) perovskite crystals were formed as a cubic system with a $1 \times 1 \times 1$ single cell. The cation of $\mathrm{MA}^{+}$, $\mathrm{EA}^{+}, \mathrm{Na}^{+}, \mathrm{K}^{+}, \mathrm{Rb}^{+}$, or $\mathrm{Cs}^{+}$was set in the center position of the unit cell $(1 \times 1 \times 1)$. The cation of $\mathrm{Pb}^{2+}$ or $\mathrm{Cu}^{2+}$ ion was set at the position of $\Gamma(0,0,0)$. As the $\mathrm{Cu}$-incorporated perovskite crystal modelling with $2 \times 2 \times 2$ supercells, parts of the $\mathrm{Pb}$ atom at the B-sites were substituted with $\mathrm{Cu}$ ion for one-atom substitution at the center of the cubic structure. The $\mathrm{Cu}$-incorporated $\mathrm{ABX}_{3}\left(\mathrm{~A}=\mathrm{MA}^{+}, \mathrm{EA}^{+}\right.$, or $\mathrm{Na}^{+}, \mathrm{X}=\mathrm{I}^{-}$or $\left.\mathrm{Br}^{-}\right)$perovskite crystals were constructed with the $2 \times 2 \times 2$ supercells, and were used for the band calculation. The band structures, effective mass and band gap were analyzed for the Brillouin zone of the lattice of the perovskite crystals along the direction of wave vector. Path for $\mathrm{ABX}_{3}$ perovskite crystal were set as follows, $\Gamma(0,0,0) \rightarrow \mathrm{X}\left(0, \frac{1}{2}, 0\right) \rightarrow \mathrm{M}(1 / 2,1 / 2,0) \rightarrow \Gamma \rightarrow \mathrm{R}(1 / 2,1 / 2,1 / 2) \rightarrow \mathrm{X}$, $\mathrm{M} \rightarrow \mathrm{R}$. The Fermi energy was set at zero. The density of states (DOS) and partial density of states (pDOS) were calculated to make clear the energy level for each orbital near the valence band (VB) and conduction band (CB). Structural optimization was performed for the structural models containing the alkali metals. The cut-off energy of the planar wave- 
function was set to $80 \mathrm{eV}$ for the structural optimization and it was set to $25 \mathrm{eV}$ for the other calculations. A $4 \times 4 \times 4 k$-point mesh was used for calculations of all structures [46-48].

F-doped tin oxide (FTO) substrates were cleaned in an ultrasonic bath with acetone and methanol and dried under nitrogen gas. The $\mathrm{TiO}_{2}(0.15$ and $0.30 \mathrm{M})$ precursor solutions were prepared from titanium diisopropoxide bis(acetyl acetonate) (Sigma-Aldrich, Tokyo, Japan, 0.055 and $0.11 \mathrm{~mL}$ ) with 1-butanol $(1 \mathrm{~mL})$. The $0.15 \mathrm{M} \mathrm{TiO}_{2}$ precursor solution was spin-coated on the FTO substrate at $3000 \mathrm{rpm}$ for $30 \mathrm{~s}$, and the coated substrate was then annealed at $125^{\circ} \mathrm{C}$ for $5 \mathrm{~min}$. The $0.30 \mathrm{M} \mathrm{TiO}_{2}$ precursor solution was spin-coated on the $\mathrm{TiO}_{2}$ layer at $3000 \mathrm{rpm}$ for $30 \mathrm{~s}$, and the resulting substrate was annealed at $125{ }^{\circ} \mathrm{C}$ for $5 \mathrm{~min}$. The process to form the $0.30 \mathrm{M}$ precursor layer was performed twice. Then, the FTO substrate was sintered at $550{ }^{\circ} \mathrm{C}$ for $30 \mathrm{~min}$ to form a compact $\mathrm{TiO}_{2}$ layer. To form the mesoporous $\mathrm{TiO}_{2}$ layer, a $\mathrm{TiO}_{2}$ paste was prepared from the $\mathrm{TiO}_{2}$ powder (Aerosil, Tokyo, Japan, P-25, $200 \mathrm{mg}$ ) with poly(ethylene glycol) (Nacalai Tesque, Kyoto, Japan, PEG \#20000, $20 \mathrm{mg}$ ) in ultrapure water [49]. The solution was mixed with acetylacetone (Fujifilm Wako Pure Chemical Corporation, Osaka, Japan, $20 \mathrm{~mL}$ ) and surfactant (Sigma-Aldrich, Tokyo, Japan, Triton X-100, $10 \mathrm{~mL}$ ) for $30 \mathrm{~min}$. Then, the $\mathrm{TiO}_{2}$ paste was spin-coated on the compact $\mathrm{TiO}_{2}$ layer at $5000 \mathrm{rpm}$ for $30 \mathrm{~s}$. The resulting cell was annealed at $550{ }^{\circ} \mathrm{C}$ for $30 \mathrm{~min}$ to form the mesoporous $\mathrm{TiO}_{2}$ layer.

To prepare the perovskite compounds, mixed solutions of $\mathrm{CH}_{3} \mathrm{NH}_{3} \mathrm{I}(2.4 \mathrm{M}$, Showa Chemical, Tokyo, Japan) and $\mathrm{PbCl}_{2}$ (0.8 M, Sigma-Aldrich, St. Louis, MO, USA) in N,Ndimethylformamide (DMF, Sigma-Aldrich, $0.5 \mathrm{~mL}$ ) were prepared for the standard cell. $\mathrm{Pb}$ or MA in the perovskite structure was expected to be substituted by $\mathrm{Cu}, \mathrm{Na}$ or EA, respectively. These perovskite solutions were then introduced into the $\mathrm{TiO}_{2}$ mesopores by spin-coating at $2000 \mathrm{rpm}$ for $60 \mathrm{~s}$, which is followed by annealing in air. During the spincoating, a hot air-blowing method was applied [50]. Temperatures of the cells during the air-blowing were set at $90^{\circ} \mathrm{C}$. A polysilane solution was prepared by mixing chlorobenzene (Fujifilm Wako Pure Chemical Corporation, $0.5 \mathrm{~mL}$ ) with decaphenylcyclopentasilane (DPPS, Osaka Gas Chemicals, Osaka, Japan, OGSOL SI-30-15, $10 \mathrm{mg}$ ). During the last $15 \mathrm{~s}$ of the third spin-coating of the perovskite precursor solutions, the DPPS polysilane solution was also spin-coated on the perovskite layer [51-54]. After the spin-coating, the thin films were annealed from 90 to $160{ }^{\circ} \mathrm{C}$ in steps of $10^{\circ} \mathrm{C}$, holding each temperature for $10 \mathrm{~min}$ [55]. The temperature rising rate is $\sim 5^{\circ} \mathrm{C} \mathrm{min}^{-1}$, which was not included in the annealing time.

A hole-transport layer was prepared by spin-coating. A solution of spiro-OMeTAD (Fujifilm Wako Pure Chemical Corporation, Osaka, Japan, $36.1 \mathrm{mg}$ ) in chlorobenzene (Fujifilm Wako Pure Chemical Corporation, $0.5 \mathrm{~mL}$ ) was mixed with a solution of lithium bis(trifluoromethylsulfonyl)imide (Li-TFSI, Tokyo Chemical Industry, Tokyo, Japan, $260 \mathrm{mg}$ ) in acetonitrile (Nacalai Tesque, Kyoto, Japan, $0.5 \mathrm{~mL}$ ) and tris(2-(1H-pyrazol-1-yl)-4-tert-butyl pyridine)cobalt(III) tri[bis(trifluoromethane)sulfonimide] (FK209, Sigma-Aldrich, $188 \mathrm{mg}$ ) in acetonitrile $(0.5 \mathrm{~mL})$ for $24 \mathrm{~h}$. The former solution with 4-tertbutylpyridine (SigmaAldrich, $0.018 \mathrm{~mL})$ was mixed with the Li-TFSI solution $(0.010 \mathrm{~mL})$ and FK209 solution $(0.004 \mathrm{~mL})$ for $30 \mathrm{~min}$ at $70{ }^{\circ} \mathrm{C}$. Then, the spiro-OMeTAD solution was spin-coated on the perovskite layer at $4000 \mathrm{rpm}$ for $30 \mathrm{~s}$. All procedures were performed in ambient air. Finally, gold $(\mathrm{Au})$ electrodes were evaporated as top electrodes using a metal mask for the patterning.

\section{Results and Discussion}

First-principles calculated band structures and partial density of states are shown in Figure 1; parameters are listed in Table 1. Figure 1a-d shows the effects of halogen substitution. For $\mathrm{MAPbI}_{3}$, the energy gap increased when I was replaced with $\mathrm{Br}$ or $\mathrm{Cl}$. An increase in the energy gap would increase the open-circuit voltage. Both the effective mass ratio of electrons, in the case of total $\mathrm{Br}$ substitution, and that of holes, in the case of total $\mathrm{Cl}$ substitution, increased relative to those values for $\mathrm{MAPbI}_{3}$. Because of the inverse relationship between effective mass and carrier mobility, it was expected that carrier mobilities would decrease when $\mathrm{Br}$ or $\mathrm{Cl}$ was added. However, for the three 
halogens in MAPbClBrI in Figure 1d, the effective mass ratios of the carriers were not significantly different from those of $\mathrm{MAPbI}_{3}$, and the energy gap increased.

Table 1 shows the total energy per unit cell of the structure model; a small value indicates a more stable crystal structure. Therefore, because the total energy decreased by replacing I with $\mathrm{Br}$ or $\mathrm{Cl}$, the crystal structure was expected to be more stable.

(a)
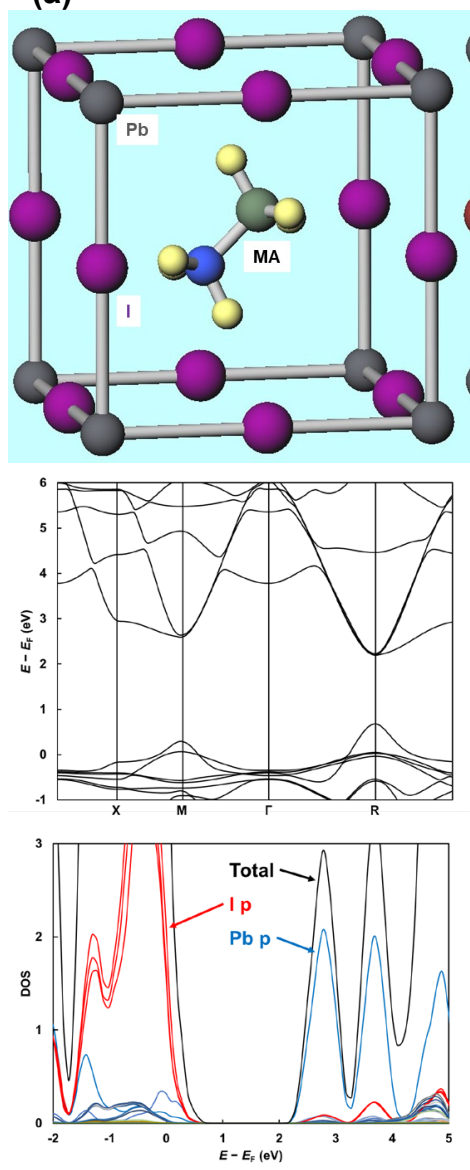

(b)
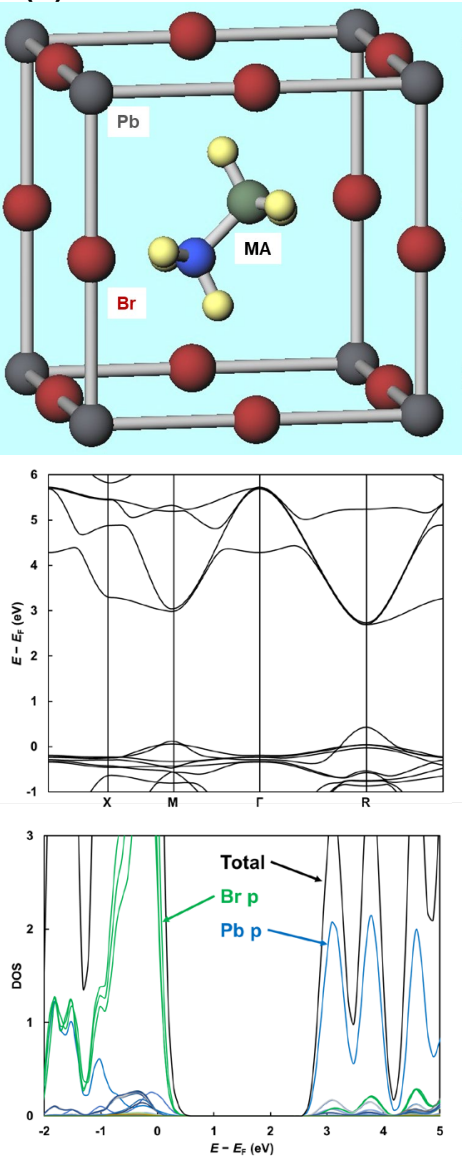

(c)
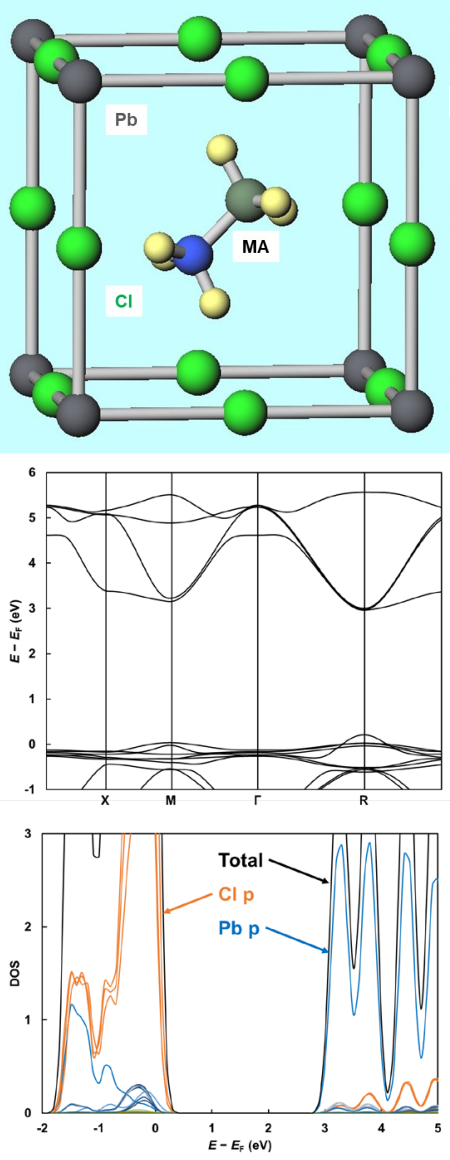

(d)
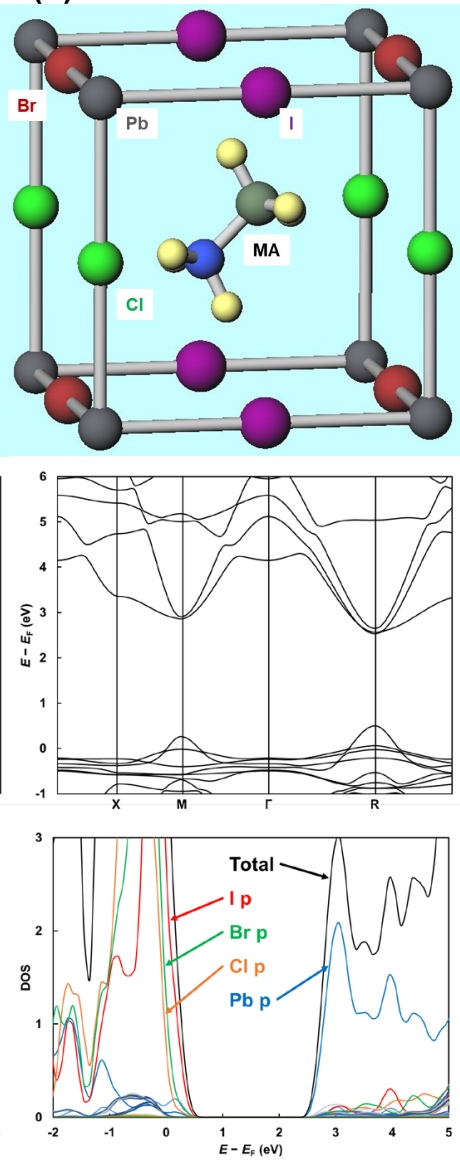

Figure 1. Calculated band structures and DOS of (a) $\mathrm{MAPbI}_{3}$, (b) $\mathrm{MAPbBr}_{3}$, (c) $\mathrm{MAPbCl}_{3}$, and (d) MAPbClBrI.

Figure $2 \mathrm{a}-\mathrm{c}$ shows the calculated results when the organic and metal cations were replaced with EA and $\mathrm{Cu}$. The horizontal axis of the figure represents the wavenumber vector, and each symbol represents a symmetry point in reciprocal lattice space, as follows: $\Gamma(0,0,0), \mathrm{X}(0,1 / 2,0), \mathrm{M}(1 / 2,1 / 2,0)$, and $\mathrm{R}(1 / 2,1 / 2,1 / 2)$. The addition of EA increased the crystal stability, in good agreement with previous studies [30]. When $\mathrm{Pb}$ was replaced by $\mathrm{Cu}$, the hole mobility was expected to increase. However, the crystal stability would decrease. For $\mathrm{EACuI}_{3}$ in Figure 1c, the total energy was lower than that of $\mathrm{MACuI}_{3}$, indicating structure stabilization by EA substitution in the presence of $\mathrm{Cu}$. 
Table 1. Calculated parameters of various perovskite compounds.

\begin{tabular}{ccccc}
\hline & Total Energy (keV) & Energy Gap (eV) & $m_{\mathbf{e}}{ }^{*} / m_{\mathbf{0}}$ & $m_{\mathbf{h}}{ }^{*} / m_{\mathbf{0}}$ \\
\hline $\mathrm{MAPbI}_{3}$ & -3.50 & 1.51 & 0.071 & 0.100 \\
$\mathrm{MAPbBr}_{3}$ & -3.66 & 2.26 & 0.224 & 0.100 \\
$\mathrm{MAPbCl}_{3}$ & -3.78 & 2.75 & 0.144 & 0.462 \\
$\mathrm{MAPbClBrI}_{\mathrm{MACuI}}$ & -3.64 & 2.03 & 0.092 & 0.102 \\
$\mathrm{EAPbI}_{3}$ & -2.52 & 1.48 & 0.136 & 0.079 \\
$\mathrm{EACuI}_{3}$ & -3.68 & 1.43 & 0.076 & 0.104 \\
$\mathrm{NaPbI}_{3}$ & -2.71 & 1.42 & 0.097 & 0.080 \\
$\mathrm{KPbI}_{3}$ & -2.99 & 1.06 & 0.077 & 0.062 \\
$\mathrm{RbPbI}_{3}$ & -3.00 & 1.04 & 0.068 & 0.062 \\
$\mathrm{CsPbI}_{3}$ & -3.00 & 1.03 & 0.067 & 0.062 \\
\hline
\end{tabular}

(a)
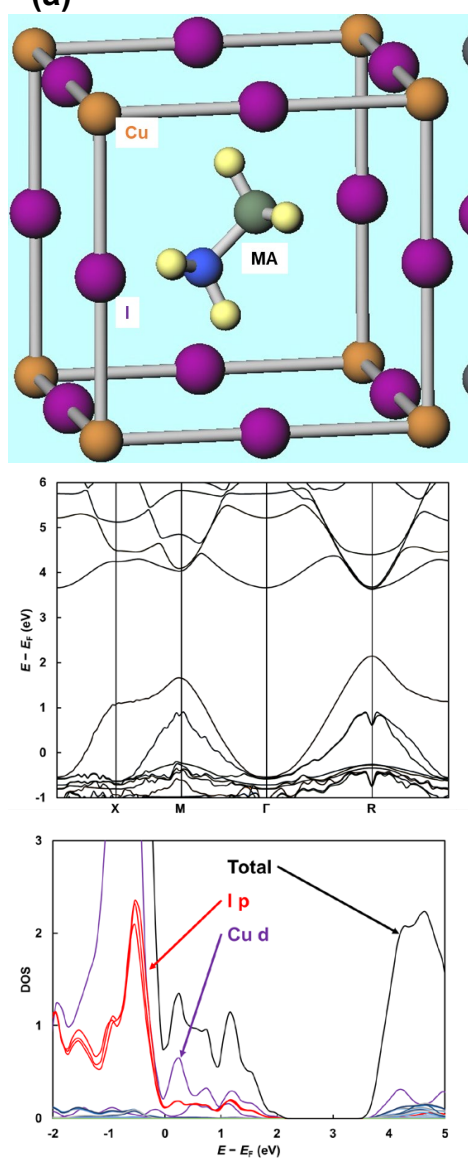

(b)
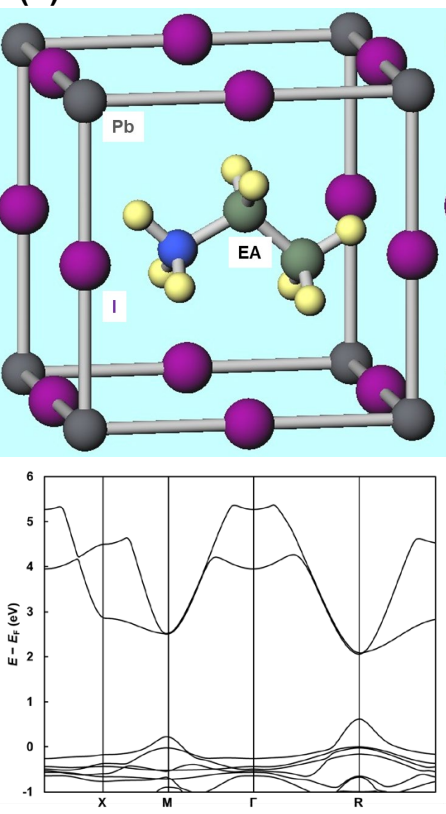

(c)
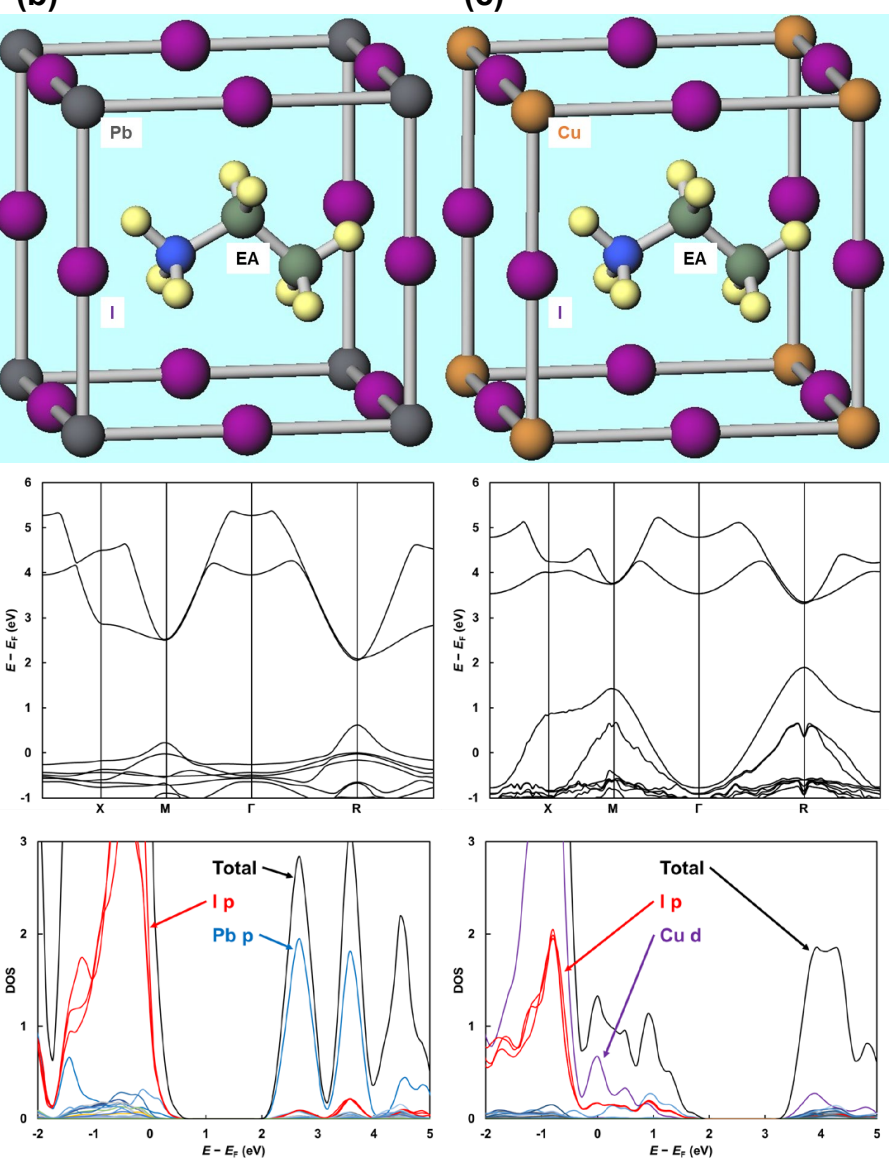

Figure 2. Calculated band structures and DOS of $(\mathbf{a}) \mathrm{MACuI}_{3},(\mathbf{b}) \mathrm{EAPbI}_{3}$, and (c) $\mathrm{EACuI}_{3}$.

Figure 3a-d shows the calculated results when the organic cation was replaced by an alkali metal. Although there were no significant differences in the resulting parameters, there was a difference in the energy level of the alkali-metal band that was formed slightly above the conduction band minimum. 
(a)
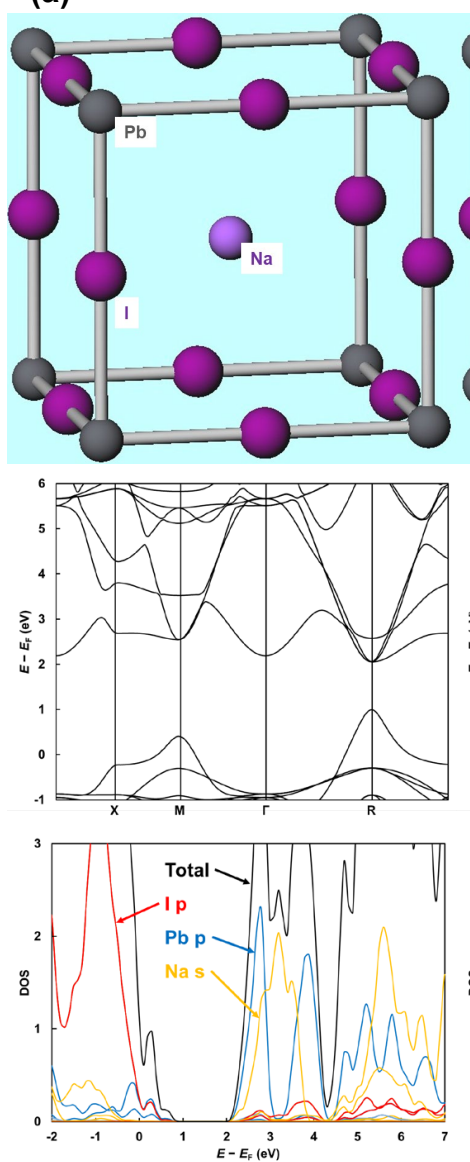

(b)
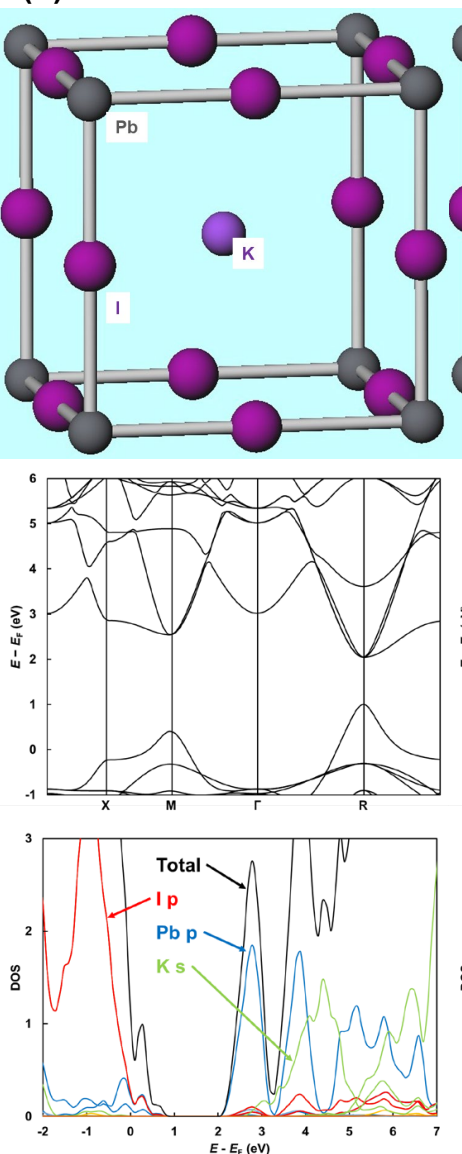

(c)

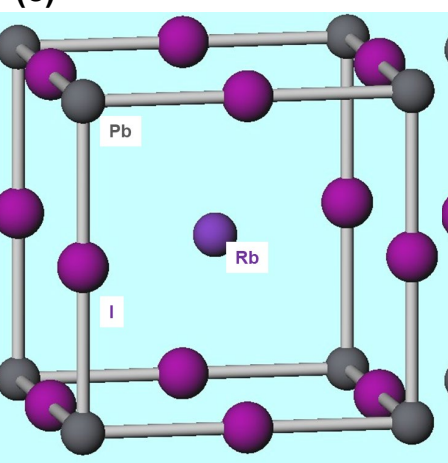

(d)
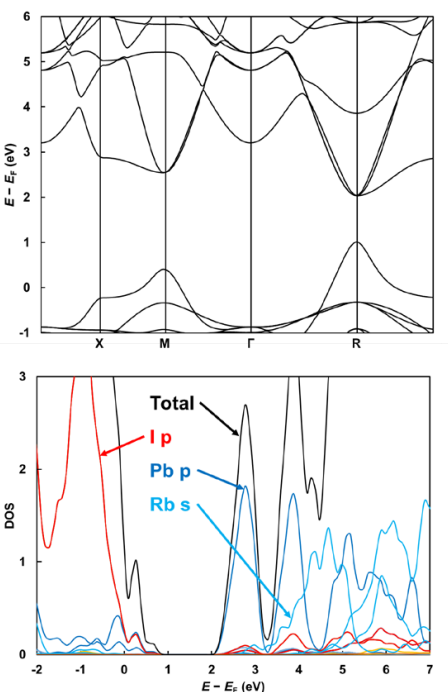
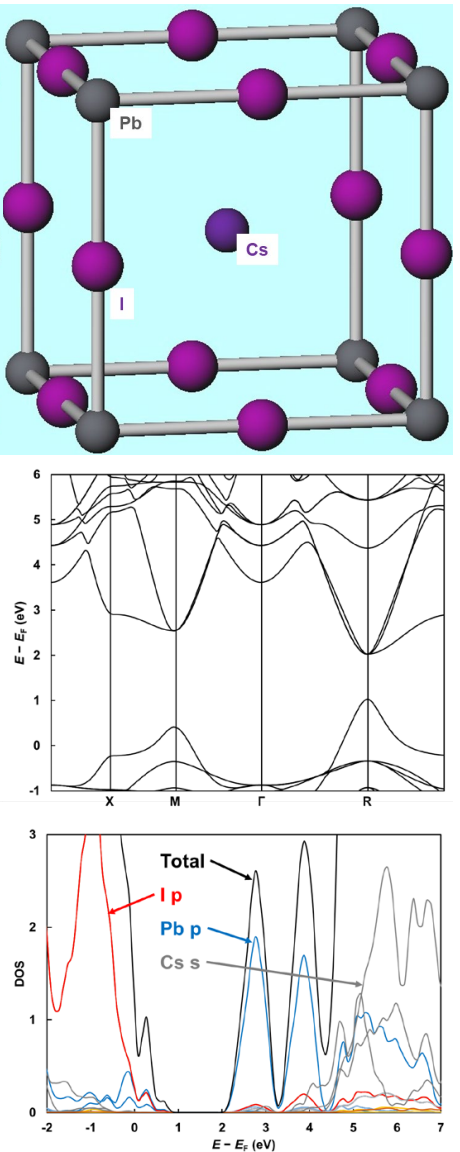

Figure 3. Calculated band structures and DOS of (a) $\mathrm{NaPbI}_{3},(\mathbf{b}) \mathrm{KPbI}_{3}$, (c) $\mathrm{RbPbI}_{3}$ and (d) $\mathrm{CsPbI}_{3}$.

The calculated band structures and partial density of states of the partial-substitution structure models are shown in Figure 4. These models contained more atoms than the total-substitution structure models, and thus required more time for the band calculations. In contrast to Figure $4 a$, where one of the eight MA molecules was replaced with EA, the addition of $\mathrm{Cu}$ resulted in the formation of a shallow band of $\mathrm{Cu}$ d-orbitals slightly above the band of I p-orbitals. This decreased the energy gap and hole mobility. Furthermore, comparing Figure $4 b, c$, the partial substitution of Na for some of the MA resulted in a band of Na s-orbitals slightly above the conduction band minimum and a slight increase in electron mobility. In Figure 4d, the energy gap was increased by substituting some of the I with Br, which was in good agreement with the calculated results for the totalsubstitution structure model. An increased effective mass for holes was attributed to $3 \mathrm{~d}$-orbital localization, as shown in Table 2. 
(a)
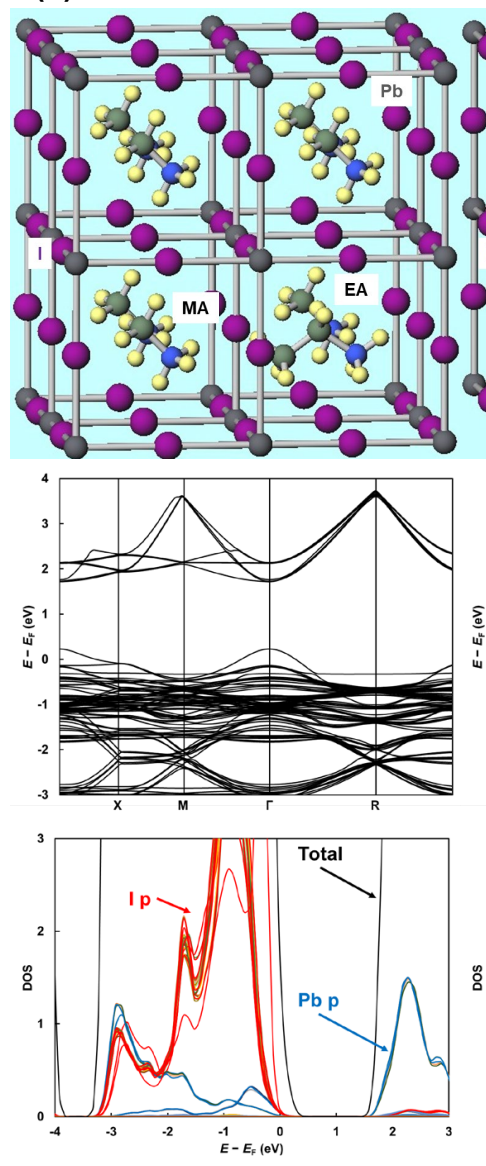

(b)

(c)
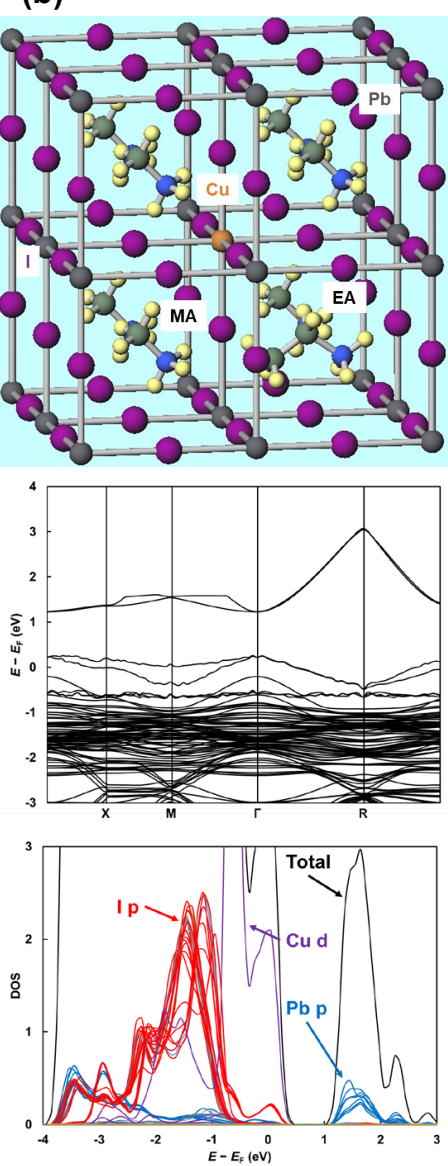
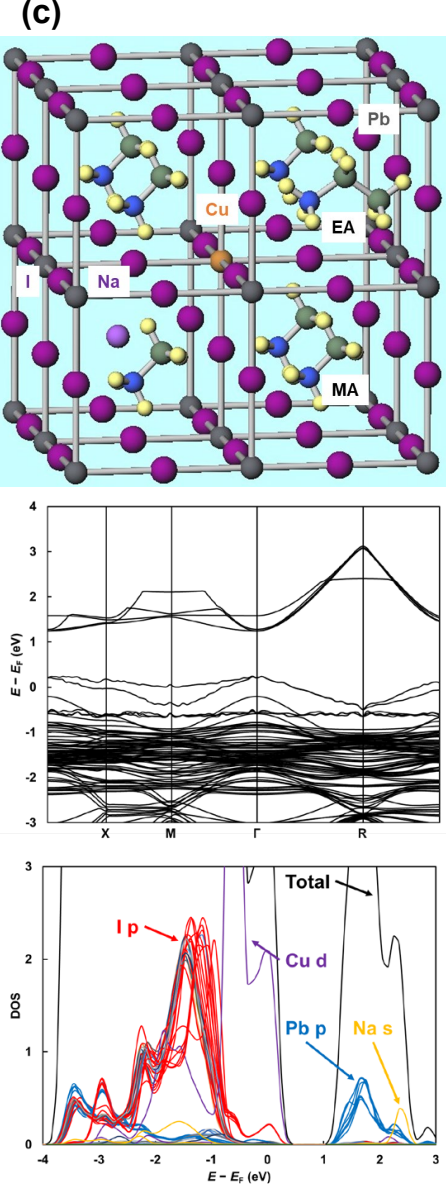

(d)
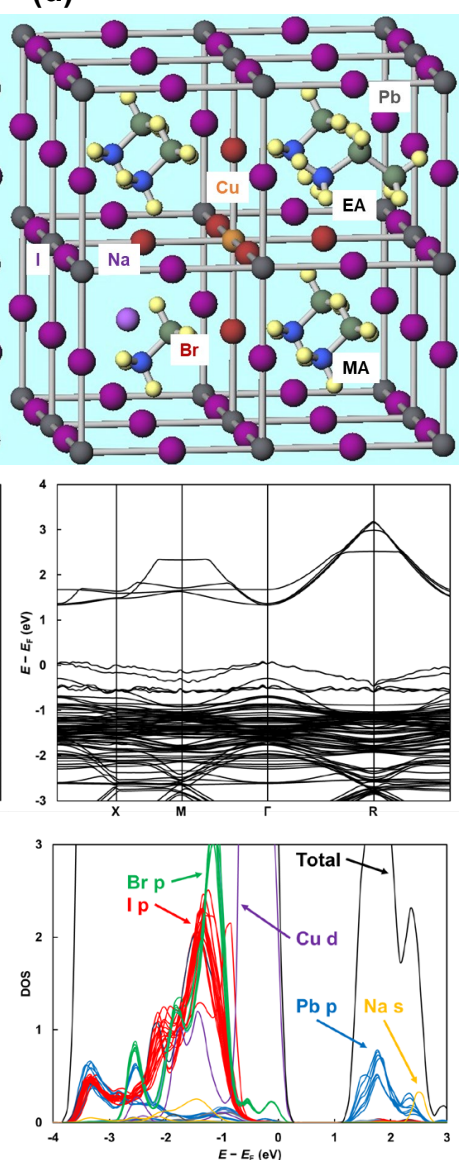

Figure 4. Calculated band structures and DOS of (a) $\mathrm{MA}_{0.875} \mathrm{EA}_{0.125} \mathrm{PbI}_{3}$, (b) $\mathrm{MA}_{0.875} \mathrm{EA}_{0.125} \mathrm{~Pb}_{0.875}$ $\mathrm{Cu}_{0.125} \mathrm{I}_{3}$, (c) $\mathrm{MA}_{0.750} \mathrm{EA}_{0.125} \mathrm{Na}_{0.125} \mathrm{~Pb}_{0.875} \mathrm{Cu}_{0.125} \mathrm{I}_{3}$ and (d) $\mathrm{MA}_{0.750} \mathrm{EA}_{0.125} \mathrm{Na}_{0.125} \mathrm{~Pb}_{0.875} \mathrm{Cu}_{0.125} \mathrm{I}_{2.25} \mathrm{Br}_{0.75}$.

Table 2. Calculated parameters of partially substituted perovskite compounds.

\begin{tabular}{ccccc}
\hline & Total Energy (keV) & Energy Gap (eV) & $m_{\mathbf{e}}{ }^{*} / m_{\mathbf{0}}$ & $m_{\mathbf{h}}{ }^{*} / m_{\mathbf{0}}$ \\
\hline $\mathrm{MA}_{0.875} \mathrm{EA}_{0.125} \mathrm{PbI}_{3}$ & -3.52 & 1.49 & 0.228 & 0.199 \\
$\mathrm{MA}_{0.875} \mathrm{EA}_{0.125} \mathrm{~Pb}_{0.875} \mathrm{Cu}_{0.125} \mathrm{I}_{3}$ & -3.39 & 1.00 & 0.266 & 0.352 \\
$\mathrm{MA}_{0.750} \mathrm{EA}_{0.125} \mathrm{Na}_{0.125} \mathrm{~Pb}_{0.875} \mathrm{Cu}_{0.125} \mathrm{I}_{3}$ & -3.32 & 1.04 & 0.241 & 0.355 \\
$\mathrm{MA}_{0.750} \mathrm{EA}_{0.125} \mathrm{Na}_{0.125} \mathrm{~Pb}_{0.875} \mathrm{Cu}_{0.125} \mathrm{I}_{2.25} \mathrm{Br}_{0.75}$ & -3.36 & 1.30 & 0.250 & 0.490 \\
\hline
\end{tabular}

Figure 5 shows experimental current-voltage curves obtained from perovskite photovoltaic devices. Detailed parameters in Table 3 indicated the effects of additives on device performances. From the calculated results on the partial substitution structure models in Figure 4, it was expected that the addition of $\mathrm{Cu}$ would decrease the energy gap and reduce hole mobility. However, the results in Table 3 indicated that co-addition of $\mathrm{Cu}$ and $\mathrm{Na}$ slightly increased the energy gap, the short-circuit current density $\left(J_{S C}\right)$, the open-circuit voltage $\left(V_{\mathrm{OC}}\right)$, and the fill factor $(F F)$, resulting in a higher conversion efficiency. Figure $1 \mathrm{a}, \mathrm{b}$ shows that the energy gap increased when I was replaced by $\mathrm{Br}$, and the $V_{\mathrm{OC}}$ enhancement from the increased energy gap could be considered an effect of Br addition. The reason for the slight $J_{\mathrm{SC}}$ increase was attributed to increased carrier generation resulting from the acceptor-level $\mathrm{Cu}$ d-orbital band. The additional excitations from the $\mathrm{Cu}$ d-orbital to the Na s-orbital would also promote carrier generation. 


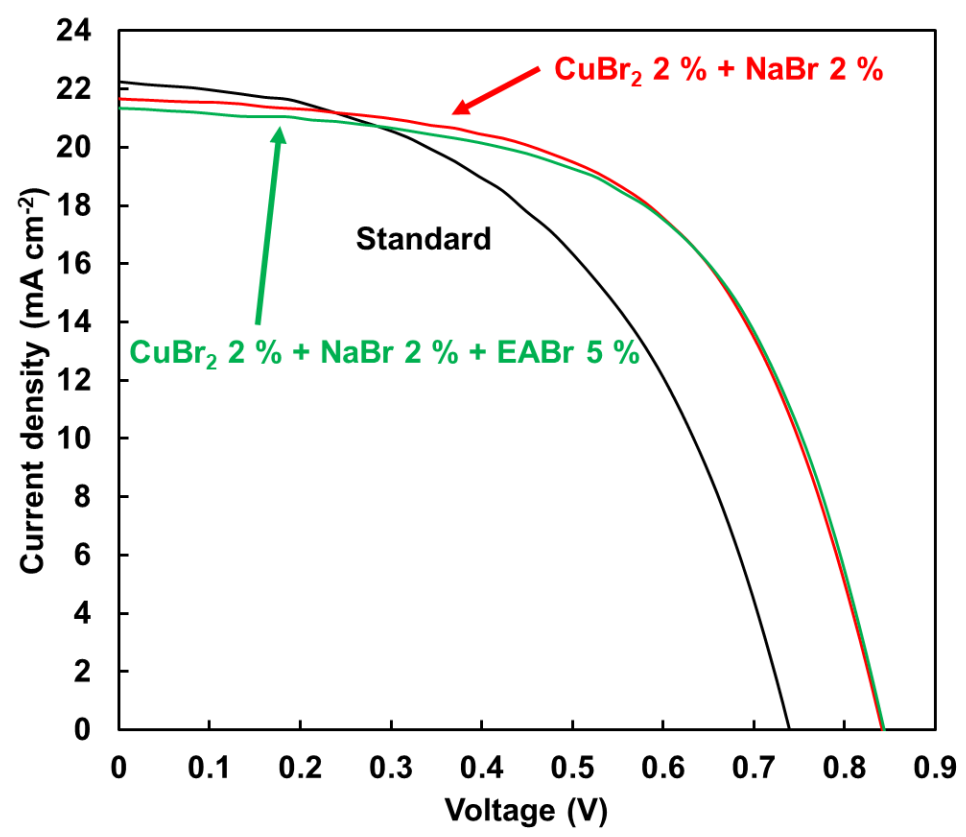

Figure 5. $J-V$ characteristics of the present perovskite solar cells.

Table 3. Measured device parameters of perovskite solar cells.

\begin{tabular}{|c|c|c|c|c|c|c|c|c|}
\hline Devices & $\begin{array}{c}J_{S C} \\
\left(\mathrm{~mA} \mathrm{~cm}^{-2}\right)\end{array}$ & $\begin{array}{l}V_{\text {OC }} \\
\text { (V) }\end{array}$ & $F F$ & $\begin{array}{c}R_{S} \\
\left(\Omega \mathrm{cm}^{2}\right)\end{array}$ & $\begin{array}{c}R_{\mathrm{Sh}} \\
\left(\Omega \mathrm{cm}^{2}\right)\end{array}$ & $\begin{array}{c}\eta \\
(\%)\end{array}$ & $\begin{array}{l}\eta_{\text {ave }} \\
(\%)\end{array}$ & $E_{\mathrm{g}}$ \\
\hline Standard & 22.2 & 0.739 & 0.497 & 4.18 & 383 & 8.17 & 5.82 & 1.55 \\
\hline $\mathrm{Cu} 2 \%+\mathrm{Na} 2 \%$ & 21.7 & 0.841 & 0.578 & 5.93 & 594 & 10.5 & 8.36 & 1.56 \\
\hline $\mathrm{Cu} 2 \%+\mathrm{Na} 2 \%+\mathrm{EA} 2.5 \%$ & 20.0 & 0.811 & 0.559 & 6.55 & 604 & 9.08 & 7.20 & 1.56 \\
\hline $\mathrm{Cu} 2 \%+\mathrm{Na} 2 \%+\mathrm{EA} 5 \%$ & 21.3 & 0.843 & 0.585 & 5.12 & 558 & 10.5 & 8.67 & 1.57 \\
\hline $\mathrm{Cu} 2+\mathrm{Na} 2 \%+\mathrm{EA} 10 \%$ & 16.1 & 0.824 & 0.586 & 5.29 & 445 & 7.78 & 5.77 & 1.57 \\
\hline
\end{tabular}

Previously [29], the co-addition of 2\% $\mathrm{Cu}$ and $2 \% \mathrm{Na}$ exhibited the highest conversion efficiency. When the amount of EA was varied, in addition to $2 \% \mathrm{Cu}$ and $2 \% \mathrm{Na}$, the highest conversion efficiency was obtained with 5\% EA. For the device with the lowest amount of $\mathrm{EABr}$, the effect of increasing the energy gap and $V_{\mathrm{OC}}$ was small because of the low bromine content. A comparatively small value of $J_{\mathrm{SC}}$ was obtained for the device with the highest amount of EABr. In Table 1, the calculated effective mass ratio for the electrons increased when I was replaced with Br. Hence, the electron mobility decreased with the addition of $\mathrm{Br}$, decreasing $J_{\text {SC. }}$. The devices doped with $\mathrm{Cu}-\mathrm{Na}$ and $\mathrm{Cu}-\mathrm{Na}-\mathrm{EA}$ exhibited the same conversion efficiencies. From the density of states in Figure 2b, no peaks corresponding to $\mathrm{C}$ or $\mathrm{N}$ were observed near the conduction-band minimum or the valence-band maximum. Thus, the substitution of MA with EA was estimated to have no special effect on the electronic structures. Furthermore, because there was almost no difference in the effective mass ratios of carriers between $\mathrm{MAPbI}_{3}$ and $\mathrm{EAPbI}_{3}$ (Table 1), the two devices had similar conversion efficiencies. However, there was a difference in the durability of the devices. The conversion efficiency of the device doped with $\mathrm{Cu}$ and $\mathrm{Na}$ decreased to $79.1 \%$ of the initial value after four weeks, while that of the device containing $2 \% \mathrm{Cu}, 2 \% \mathrm{Na}$, and $5 \% \mathrm{EABr}$ remained at $96.2 \%$ of its initial value. The total-energy calculation results in Table 1 indicate that the crystal structure was destabilized when $\mathrm{Pb}$ and MA were replaced with $\mathrm{Cu}$ and $\mathrm{Na}$, respectively. The devices with $\mathrm{Cu}, \mathrm{Na}$, and EA exhibited higher durabilities than devices with just $\mathrm{Cu}$ and $\mathrm{Na}$, which confirmed that the addition of EA stabilized the crystal structure. Therefore, the addition of organic cations more stable than MA to Cu-based perovskites enhanced the durability. It was also expected 
that the device durability was highly dependent on the stability of the perovskite crystal, and that the durability could be estimated by the calculated total energy.

Figure 6 shows X-ray diffraction (XRD) measurements for the $\mathrm{MAPbI}_{3}$ device and those doped with $\mathrm{Cu}, \mathrm{Na}$, and EA. Table 4 shows the measaured structural parameters calculated from the XRD data. A diffraction peak corresponding to tetragonal (211) planes was observed at $23.5^{\circ}$. The peak intensity was slightly lower in the doped devices relative to that for $\mathrm{MAPbI}_{3}$, suggesting that elimination of lattice distortion by the substitution of $\mathrm{Pb}$ with $\mathrm{Cu}$ reduced the peak intensity. Although the ionic radii of $\mathrm{Cu}$ and $\mathrm{Na}$ are smaller than those of $\mathrm{Pb}$ and $\mathrm{MA}$, their additions increased the lattice constant. The crystal lattice was expanded by the presence of $\mathrm{Na}$ in the interstitial position relative to that of MA. The lattice constants of devices doped with $\mathrm{Cu}, \mathrm{Na}$, and EA were the smallest, because of I substitution with $\mathrm{Br}$, which had a smaller ionic radius. Crystallites of $\mathrm{MAPbI}_{3}$ were larger than those of the doped devices. Previously, $\mathrm{CuBr}_{2}$ addition to the perovskite precursor solution slowed the crystallization rate of the perovskite film, and decreased the crystallite size and diffraction-peak intensity. During annealing of the perovskite film, the color-changing rates with added $\mathrm{Cu}$ and $\mathrm{Na}$ were slower than those of $\mathrm{MAPbI}_{3}$, indicating that the addition of $\mathrm{CuBr}_{2}$ decreased the crystallization rate.

Figure 7 shows optical microscopy images of perovskite crystals in actual devices. In $\mathrm{MAPbI}_{3}$ (Figure 7a), the surface morphology was non-uniform with less coverage. The addition of $\mathrm{Cu}$ and $\mathrm{Na}$ significantly increased the surface coverage and the homogeneity, as observed in Fgure $7 \mathrm{~b}$. This suggests that the addition of $\mathrm{CuBr}_{2}$ reduced the crystallization rate, which, combined with the gradual increase of the annealing temperature, contributed to the formation of a homogeneous film. The densest and most homogeneous perovskite films were obtained for devices doped with $\mathrm{Cu}, \mathrm{Na}$, and EA, as observed in Fgure 7c. The increased crystallization with the added EA enhanced the surface morphology.

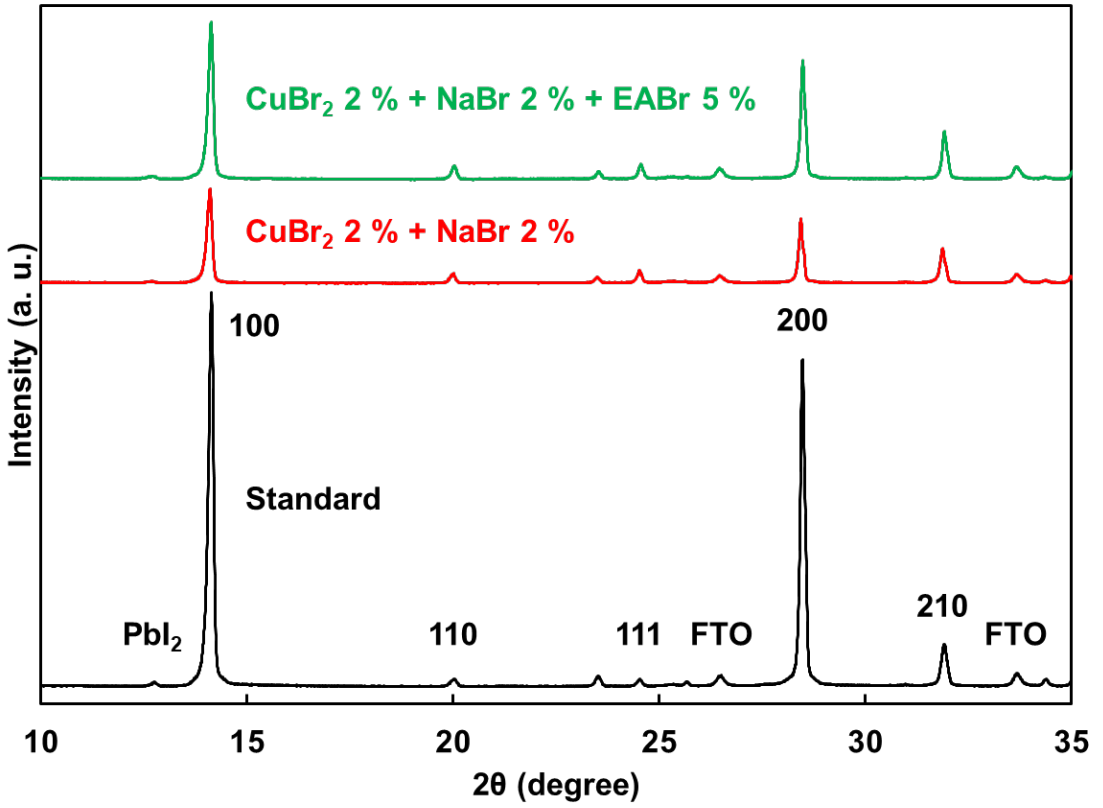

Figure 6. XRD patterns of the present perovskite solar cells.

Table 4. Measured structural parameters of perovskite crystals.

\begin{tabular}{cccc}
\hline Devices & $\boldsymbol{I}_{\mathbf{1 0 0}} / \mathbf{I}_{\mathbf{2 1 0}}$ & $\begin{array}{c}\text { Lattice Constant } \\
(\AA)\end{array}$ & $\begin{array}{c}\text { Crystallite Size } \\
(\AA)\end{array}$ \\
\hline Standard & 8.7 & $6.262(1)$ & 697 \\
$\mathrm{CuBr} 2$ 2\% NaBr 2\% & 2.6 & $6.271(1)$ & 679 \\
$\mathrm{Cu} \mathrm{Na} \% \mathrm{EABr} 5 \%$ & 3.1 & $6.261(1)$ & 674 \\
\hline
\end{tabular}



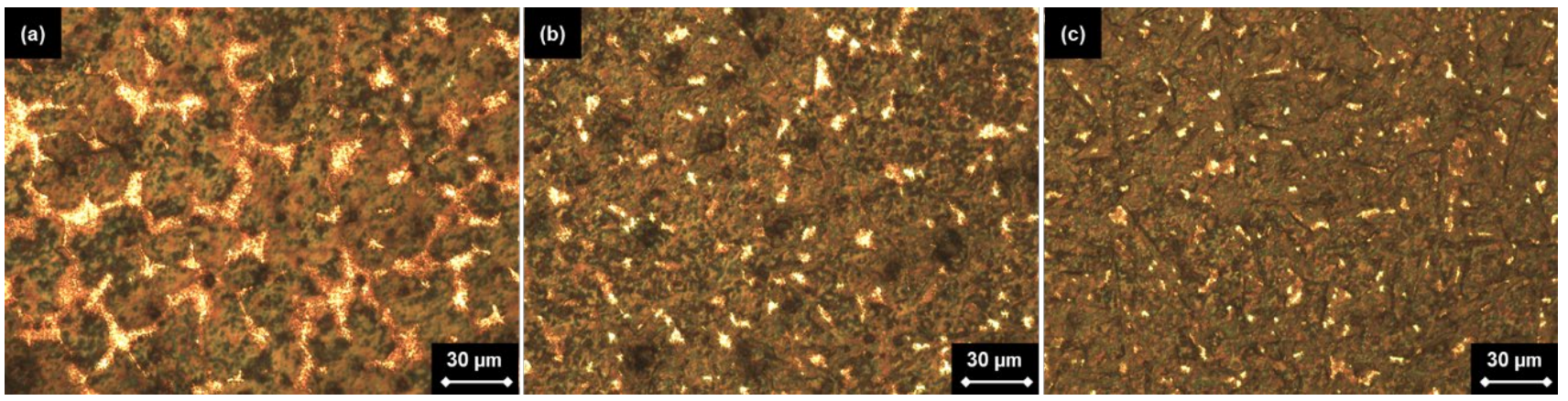

Figure 7. Optical microscopy images of the (a) standard, (b) $\mathrm{Cu}-\mathrm{Na}$, and (c) Cu-Na-EA added perovskite solar cells.

As noted earlier in the calculated results of the partial-substitution structure model (Figure 4), $\mathrm{Cu}$ addition formed a shallow band of $\mathrm{Cu}$ d-orbitals slightly above the band of iodine p-orbitals, which reduced the energy gap and decreased hole mobility. However, if the $\mathrm{Cu}$ d-orbital band was an acceptor level, it would increase the device performance. Figure 8 shows an enlarged view of the band structure in Figure 4c. At the valence band maximum, the excitation of electrons from the I p-orbitals to the $\mathrm{Cu}$ d-orbitals increased the generation of carriers and increased $J_{\mathrm{SC}}$. When only $\mathrm{Cu}$ was added, electrons excited into the $\mathrm{Cu}$ d-orbitals were de-excited to the I $\mathrm{p}$ orbitals, and generated carriers were lost via electron-hole recombinations. However, when $\mathrm{Na}$ was added, the additional excitations from the $\mathrm{Cu}$ d-orbitals to the $\mathrm{Na}$ s-orbitals reduced the possibility of de-excitation to the I p-orbitals, thus reducing the loss of generated carriers.

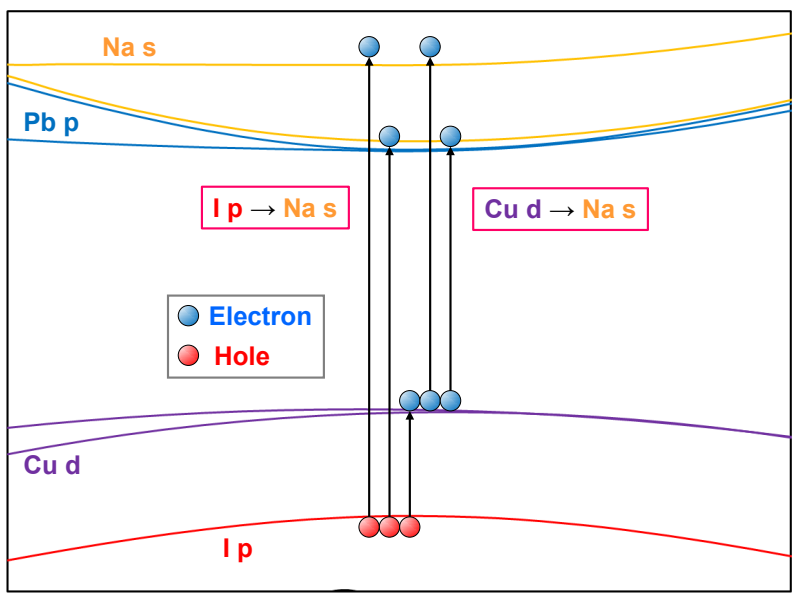

Figure 8. Model of the excitation process in band structures of $\mathrm{MA}_{0.750} \mathrm{EA}_{0.125} \mathrm{Na}_{0.125} \mathrm{~Pb}_{0.875} \mathrm{Cu}_{0.125} \mathrm{I}_{3}$.

In Figure $3 \mathrm{a}-\mathrm{d}$, the alkali-metal energy bands formed above the conduction band minimum varied with the metal. These results are summarized in Figure $9 a$, and an enlarged view of the red rectangle is shown in Figure 9b. Substitution of MA with alkali metals significantly decreased the energy gap in the order $\mathrm{Na}, \mathrm{K}, \mathrm{Rb}$, and $\mathrm{Cs}$. Because the alkali-metal additions in the actual devices were a few $\mathrm{mol} \%$, the energy gaps were not expected to decrease as much as in the calculated results for the total-substitution models. The valence band maximum increased in the order $\mathrm{Na}, \mathrm{K}, \mathrm{Rb}$, and $\mathrm{Cs}$, which indicated that the addition of $\mathrm{Rb}$ or $\mathrm{Cs}$ increased the absorption of shorter-wavelength light in the visible region. The differences in energy levels in Figure $9 \mathrm{~b}$ corresponded to energies that were higher than those of visible light. However, because the $\mathrm{Cu}$ d-orbital bands were formed at the valence band maximum by adding $\mathrm{Cu}$, the difference in energy levels between the alkali-metal bands and the $\mathrm{Cu}$ bands was approximately the same energy as that in the visible-light region. 
(a)

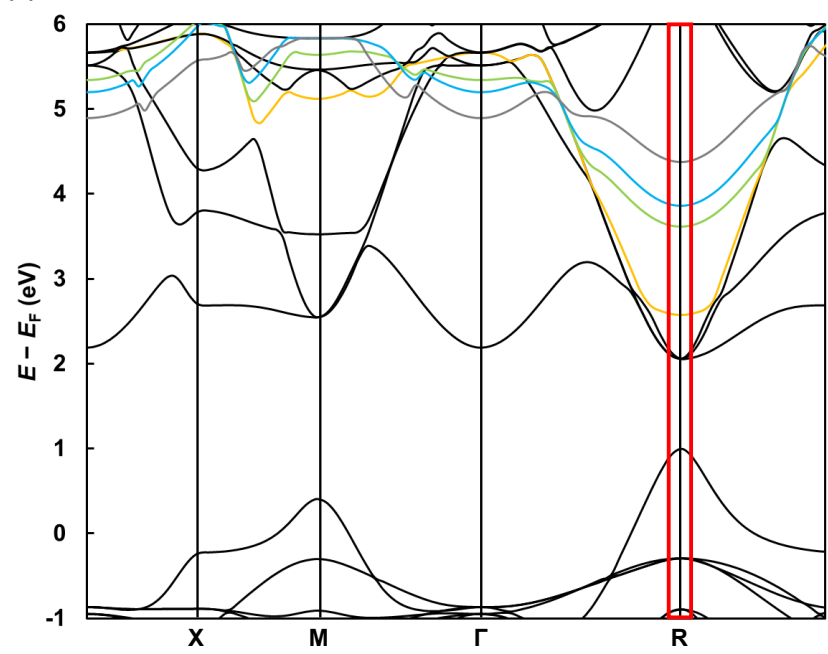

(b)

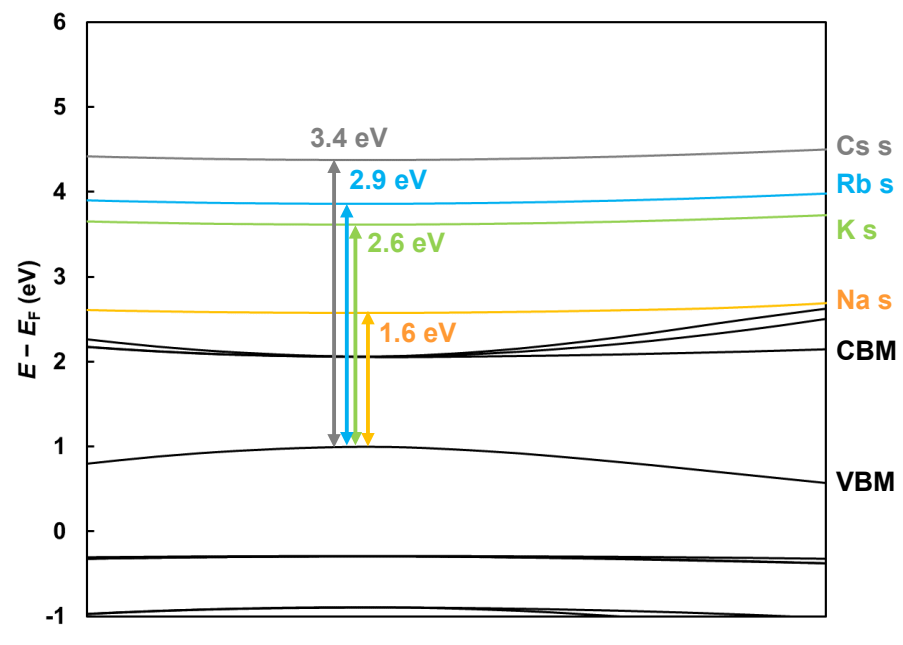

Figure 9. (a) Changes of band structures for various alkali metals. (b) Enlarged view at the band gap.

\section{Conclusions}

In summary, the effects of $\mathrm{Cu}, \mathrm{Na}$, and $\mathrm{EA}$ co-addition to $\mathrm{MAPbI}_{3}$ perovskite crystals were investigated with first-principles calculations and experimental devices. The calculations indicated that substitution of all the $\mathrm{I}$ with $\mathrm{Br}$ or $\mathrm{Cl}$ increased the energy gap and increased $V_{\text {OC }}$. These additives to the perovskite precursor solution also increased the energy gap and $V_{\mathrm{OC}}$ in all the devices relative to those of $\mathrm{MAPbI}_{3}$. When some of the $\mathrm{Pb}$ was replaced with $\mathrm{Cu}$, a shallow band of $\mathrm{Cu}$ d-orbitals formed slightly above the valence band maximum, which decreased the energy gap and reduced hole mobility. When a small amount of $\mathrm{Cu}$ was added to actual devices, the conversion efficiency and the energy gap increased slightly, which indicated that $\mathrm{Cu}$ energy levels formed in the forbidden band and functioned as acceptor levels. The excitation of electrons from the I p-orbitals to the $\mathrm{Cu}$ dorbitals generated carriers, increasing $J_{S C}$. The alkali-metal energy bands formed above the conduction band minimum, which differed for the various alkali metals. Another possible reason for the increased $J_{S C}$ was the reduced loss of generated carriers by excitations from the $\mathrm{Cu}$ d-orbitals and the I p-orbitals to the s-orbitals of the alkali metals. The total-energy calculations indicated that the substitution of $\mathrm{Pb}$ and $\mathrm{MA}$ with $\mathrm{Cu}$ and $\mathrm{Na}$, respectively, destabilized the crystal structure. When MA was replaced with EA, the crystal structure was stabilized. Thus, the addition of EA to the $\mathrm{Cu}$ and $\mathrm{Na}$ systems increased structural stability. The actual device doped with $\mathrm{Cu}, \mathrm{Na}$, and EA exhibited higher durability than that device doped with only $\mathrm{Cu}$ and $\mathrm{Na}$. Therefore, crystal stabilization by EA addition occurred, even when $\mathrm{Cu}$ and $\mathrm{Na}$ were also added. Furthermore, the durability of the devices was highly dependent on the stability of the perovskite crystals, which could be estimated by the calculated total energies. Overall, it is expected that the photoelectric conversion and durability of $\mathrm{Cu}$-based perovskite solar cells could be enhanced by adding various halogens or introducing more-stable organic cations.

Author Contributions: Conceptualization, R.O. and T.O.; Methodology, R.O., T.O. and A.S.; Formal Analysis, R.O., T.O. and A.S.; Investigation, R.O. and A.S.; Resources, M.O., S.F., T.T. and T.H.; Data Curation, R.O. and T.O.; Writing-Original Draft Preparation, R.O. and T.O.; Writing-Review and Editing, R.O., T.O., A.S., M.O., S.F., T.T. and T.H.; Project Administration, T.O.; Funding Acquisition, T.O. All authors have read and agreed to the published version of the manuscript.

Funding: This research was partly funded by Japan Society for the Promotion of Science as a Grantin-Aid for Scientific Research (C) 21K04809.

Institutional Review Board Statement: Not Applicable.

Informed Consent Statement: Not Applicable. 
Data Availability Statement: Data is contained within the article.

Conflicts of Interest: The authors declare no conflict of interest.

\section{References}

1. Wang, F.; Yang, M.; Yang, S.; Qu, X.; Yang, L.; Fan, L.; Yang, J.; Rosei, F. Iodine-assisted antisolvent engineering for stable perovskite solar cells with efficiency $>21.3 \%$. Nano Energy 2020, 67, 104224. [CrossRef]

2. Mingyu, J.; Choi, I.W.; Go, E.M.; Cho, Y.; Kim, M.; Byongkyu, L.; Seonghun, J.; Yimhyun, J.; Choi, H.W.; Lee, J.; et al. Stable perovskite solar cells with efficiency exceeding $24.8 \%$ and $0.3-\mathrm{V}$ voltage loss. Science 2020, 369, 1615-1620. [CrossRef]

3. Kim, G.; Min, H.; Lee, S.K.; Lee, Y.D.; Yoon, M.S.; Seok, I.S. Impact of strain relaxation on performance of $\alpha$-formamidinium lead iodide perovskite solar cells. Science 2020, 370, 108. [CrossRef]

4. Popov, G.; Mattinen, M.; Kemell, M.L.; Ritala, M.; Leskelä, M. Scalable route to the fabrication of $\mathrm{CH}_{3} \mathrm{NH}_{3} \mathrm{PbI}_{3}$ perovskite thin films by electrodeposition and vapor conversion. ACS Omega 2016, 1, 1296-1306. [CrossRef]

5. Zanca, C.; Piazza, V.; Agnello, S.; Patella, B.; Ganci, F.; Aiello, G.; Piazza, S.; Sunseri, C.; Inguanta, R. Controlled solution-based fabrication of perovskite thin films directly on conductive substrate. Thin Solid Film. 2021, 733, 138806. [CrossRef]

6. Duan, C.; Wen, Q.; Fan, Y.; Li, J.; Liu, Z.; Yan, K. Improving the stability and scalability of all-inorganic inverted CsPbI ${ }_{2} \mathrm{Br}$ perovskite solar cell. Energy Chem. 2022, 68, 176-183. [CrossRef]

7. Shen, L.; Zhu, T.; Zhang, X.; Gong, K.; Wang, H.; Gong, X. Bulk heterojunction perovskite solar cells incorporated with p-type low optical gap conjugated polymers. Nano Energy 2022, 93, 106907. [CrossRef]

8. Zhang, Y.; Pathak, R.; Zheng, D.; Cheng, P.; Chen, T.; Chen, X.; Wei, K.; Wang, R.; Wu, F. Synthesis of cesium bismuth iodide perovskite using toluene as anti-solvent with higher photocurrent response. Mater. Lett. 2022, 310, 131514. [CrossRef]

9. Bohr, C.; Le, K.; Fischer, T.; Mathur, S. Triaxial perovskite composite fibers spinning the way to flexible solar cells. Adv. Eng. Mater. 2021, 24, 2100773. [CrossRef]

10. Arora, N.; Dar, M.I.; Hinderhofer, A.; Pellet, N.; Schreiber, F.; Zakeeruddin, S.M.; Grätzel, M. Perovskite solar cells with CuSCN hole extraction layers yield stabilized efficiencies greater than $20 \%$. Science 2017, 358, 768-771. [CrossRef]

11. Shirahata, Y.; Oku, T. Microstructures, optical and photovoltaic properties of $\mathrm{CH}_{3} \mathrm{NH}_{3} \mathrm{PbI}_{3(1-x)} \mathrm{Cl}_{\mathrm{x}}$ perovskite films with CuSCN additive. Mater. Res. Express 2018, 5, 055504. [CrossRef]

12. Islam, M.A.; Wahab, Y.A.; Khandaker, M.U.; Alsubaie, A.; Almalki, A.S.A.; Bradley, D.A.; Amin, N. High mobility reactive sputtered $\mathrm{Cu}_{\mathrm{x}} \mathrm{O}$ thin film for highly efficient and stable perovskite solar cells. Crystals 2021, 11, 389. [CrossRef]

13. Salah, M.M.; Abouelatta, M.; Shaker, A.; Hassan, K.M.; Saeed, A. A comprehensive simulation study of hybrid halide perovskite solar cell with copper oxide as HTM. Semicond. Sci. Technol. 2019, 34, 115009. [CrossRef]

14. Haider, S.Z.; Anwar, H.; Wang, M. A comprehensive device modelling of perovskite solar cell with inorganic copper iodide as hole transport material. Semicond. Sci. Technol. 2018, 33, 035001. [CrossRef]

15. Pitriana, P.; Wungu, T.D.K.; Herman; Hidayat, R. The characteristics of band structures and crystal binding in all-inorganic perovskite $\mathrm{APbBr}_{3}$ studied by the first principle calculations using the density functional theory (DFT) method. Results Phys. 2019, 15, 102592. [CrossRef]

16. Chang, C.; Zou, X.; Cheng, J.; Ling, T.; Yao, Y.; Chen, D. Applied trace alkali metal elements for semiconductor property modulation of perovskite thin films. Molecules 2019, 24, 4039. [CrossRef] [PubMed]

17. Xiang, S.; Li, W.; Wei, Y.; Liu, J.; Liu, H.; Zhu, L.; Yang, S.; Chen, H. Natrium doping pushes the efficiency of carbon-based CsPbI 3 perovskite solar cells to $10.7 \%$. iScience 2019, 15, 156-164. [CrossRef]

18. Qiao, L.; Fang, W.H.; Long, R.; Prezhdo, O.V. Alkali metals extend carrier lifetimes in lead halide perovskites by passivating and eliminating halide interstitial defects. Angew. Chem. 2020, 132, 4714-4720. [CrossRef]

19. Zhao, W.; Yao, Z.; Yu, F.; Yang, D.; Liu, S. Alkali metal doping for improved $\mathrm{CH}_{3} \mathrm{NH}_{3} \mathrm{PbI}_{3}$ perovskite solar cells. Adv. Sci. 2018, 5, 1700131. [CrossRef]

20. Machiba, H.; Oku, T.; Kishimoto, T.; Ueoka, N.; Suzuki, A. Fabrication and evaluation of K-doped $\mathrm{MA}_{0.8} \mathrm{FA}_{0.1} \mathrm{~K}_{0.1} \mathrm{PbI}_{3}(\mathrm{Cl})$ perovskite solar cells. Chem. Phys. Lett. 2019, 730, 117-123. [CrossRef]

21. Oku, T.; Kandori, S.; Taguchi, M.; Suzuki, A.; Okita, M.; Minami, S.; Fukunishi, S.; Tachikawa, T. Polysilane-inserted methylammonium lead iodide perovskite solar cells doped with formamidinium and potassium. Energies 2020, 13, 4776. [CrossRef]

22. Kandori, S.; Oku, T.; Nishi, K.; Kishimoto, T.; Ueoka, N.; Suzuki, A. Fabrication and characterization of potassium- and formamidinium-added perovskite solar cells. J. Ceram. Soc. Jpn. 2020, 128, 805. [CrossRef]

23. Boopathi, K.M.; Mohan, R.; Huang, T.Y.; Budiawan, W.; Lin, M.Y.; Lee, C.H.; Ho, K.C.; Chu, C.W. Synergistic improvements in stability and performance of lead iodide perovskite solar cells incorporating salt additives. J. Mater. Chem. A 2016, 4, 1591. [CrossRef]

24. Wang, K.L.; Wang, R.; Wang, Z.K.; Li, M.; Zhang, Y.; Ma, H.; Liao, L.S.; Yang, Y. Tailored phase transformation of CsPbI 2 Br films by copper (II) bromide for high-performance all-inorganic perovskite solar cells. Nano Lett. 2019, 19, 5176-5184. [CrossRef]

25. Li, M.; Wang, Z.K.; Zhuo, M.P.; Hu, Y.; Hu, K.H.; Ye, Q.Q.; Jain, S.M.; Yang, Y.G.; Gao, X.Y.; Liao, L.S. Pb-Sn-Cu Ternary organometallic halide perovskite solar cells. Adv. Mater. 2018, 30, 1800258. [CrossRef] [PubMed] 
26. Elseman, A.M.; Shalan, A.E.; Sajid, S.; Rashad, M.M.; Hassan, A.M.; Li, M. Copper-substituted lead perovskite materials constructed with different halides for working $\left(\mathrm{CH}_{3} \mathrm{NH}_{3}\right)_{2} \mathrm{CuX}$-based perovskite solar cells from experimental and theoretical view. ACS Appl. Mater. Interfaces 2018, 10, 11699-11707. [CrossRef] [PubMed]

27. Jahandar, M.; Heo, J.H.; Song, C.E.; Kong, K.J.; Shin, W.S.; Lee, J.C.; Im, S.H.; Moon, S.J. Highly efficient metal halide substituted $\mathrm{CH}_{3} \mathrm{NH}_{3} \mathrm{I}\left(\mathrm{PbI}_{2}\right)_{1-\chi}\left(\mathrm{CuBr}_{2}\right)_{x}$ planar perovskite solar cells. Nano Energy 2016, 27, 330-339. [CrossRef]

28. Ueoka, N.; Oku, T.; Suzuki, A. Additive effects of alkali metals on Cu-modified $\mathrm{CH}_{3} \mathrm{NH}_{3} \mathrm{PbI}_{3-\delta} \mathrm{Cl}_{\delta}$ photovoltaic devices. RSC Adv. 2019, 9, 24231-24240. [CrossRef]

29. Ueoka, N.; Oku, T. Effects of co-addition of sodium chloride and copper (II) bromide to mixed-cation mixed-halide perovskite photovoltaic devices. ACS Appl. Energy Mater. 2020, 3, 7272-7283. [CrossRef]

30. Ueoka, N.; Oku, T.; Suzuki, A. Effects of doping with $\mathrm{Na}, \mathrm{K}, \mathrm{Rb}$, and formamidinium cations on $\left(\mathrm{CH}_{3} \mathrm{NH}_{3}\right)_{0.99} \mathrm{Rb}_{0.01} \mathrm{~Pb}_{0.99} \mathrm{Cu}_{0.01} \mathrm{I}_{3-x}$ $(\mathrm{Cl}, \mathrm{Br})_{x}$ perovskite photovoltaic cells. AIP Adv. 2020, 10, 125023. [CrossRef]

31. Oku, T. Crystal structures of perovskite halide compounds used for solar cells. Rev. Adv. Mater. Sci. 2020, 59, 264-305. [CrossRef]

32. Liu, D.; Li, Q.; Wu, K. Ethylammonium as an alternative cation for efficient perovskite solar cells from first-principles calculations. RSC Adv. 2019, 9, 7356. [CrossRef]

33. Xiao, Z.; Yan, Y. Progress in theoretical study of metal halide perovskite solar cell materials. Adv. Energy Mater. 2017, 7, 1701136. [CrossRef]

34. Jung, M.H. Formation of cubic perovskite alloy containing the ammonium cation of 2D perovskite for high performance solar cells with improved stability. RSC Adv. 2021, 11, 32590. [CrossRef]

35. Nishi, K.; Oku, T.; Kishimoto, T.; Ueoka, N.; Suzuki, A. Photovoltaic characteristics of $\mathrm{CH}_{3} \mathrm{NH}_{3} \mathrm{PbI}_{3}$ perovskite solar cells added with ethylammonium bromide and formamidinium iodide. Coatings 2020, 10, 410. [CrossRef]

36. Kishimoto, T.; Oku, T.; Suzuki, A.; Ueoka, N. Additive effects of guanidinium iodide on $\mathrm{CH}_{3} \mathrm{NH}_{3} \mathrm{PbI}_{3}$ perovskite solar cells. Phys. Status Solidi A 2021, 218, 2100396. [CrossRef]

37. Mateen, M.; Arain, Z.; Liu, X.; Iqbal, A.; Ren, Y.; Zhang, X.; Liu, C.; Chen, Q.; Ma, S.; Ding, Y.; et al. Boosting optoelectronic performance of $\mathrm{MAPbI}_{3}$ perovskite solar cells via ethylammonium chloride additive engineering. Sci. China Mater. 2020, 63, 2477-2486. [CrossRef]

38. Zhang, Y.; Kim, S.G.; Lee, D.; Shin, H.; Park, N.G. Bifacial stamping for high efficiency perovskite solar cells. RSC Energy Environ. Sci. 2019, 12, 308-321. [CrossRef]

39. Dhar, A.; Dey, A.; Maiti, P.; Paul, P.K.; Roy, S.; Paul, S.; Vekariya, R.L. Fabrication and characterization of next generation nano-structured organo-lead halide-based perovskite solar cell. Ionics 2018, 24, 1-7. [CrossRef]

40. Mohebpour, M.A.; Saffari, M.; Soleimani, H.R.; Tagani, M.B. High performance of mixed halide perovskite solar cells: Role of halogen atom and plasmonic nanoparticles on the ideal current density of cell. Phys. E 2018, 97, 282-289. [CrossRef]

41. Lee, A.Y.; Park, D.Y.; Jeong, M.S. Correlational study of halogen tuning effect in hybrid perovskite single crystals with Raman scattering, X-ray diffraction, and absorption spectroscopy. J. Alloy. Compd. 2018, 738, 239-245. [CrossRef]

42. Motta, C.; El-Mellouhi, F.; Sanvito, S. Charge carrier mobility in hybrid halide perovskites. Sci. Rep. 2015, 5, 12746. [CrossRef] [PubMed]

43. Park, B.W.; Jain, S.M.; Zhang, X.; Hagfeldt, A.; Boschloo, G.; Edvinsson, T. Resonance raman and excitation energy dependent charge transfer mechanism in halide-substituted hybrid perovskite solar cells. ACS Nano 2015, 9, 2088-2101. [CrossRef] [PubMed]

44. Li, Q.; Zhao, Y.; Zhou, W.; Han, Z.; Fu, R.; Lin, F.; Yu, D.; Zhao, Q. Halogen engineering for operationally stable perovskite solar cells via sequential deposition. Adv. Energy Mater. 2019, 9, 1902239. [CrossRef]

45. Lin, P.Y.; Loganathan, A.; Raifuku, I.; Li, M.H.; Chiu, Y.Y.; Chang, S.T.; Fakharuddin, A.; Lin, C.F.; Guo, T.F.; Schmidt-Mende, L.; et al. Pseudo-halide perovskite solar cells. Adv. Energy Mater. 2021, 11, 2100818. [CrossRef]

46. Suzuki, A.; Kitagawa, K.; Oku, T.; Okita, M.; Fukunishi, S.; Tachikawa, T. Additive effects of copper and alkali metal halides into methylammonium lead iodide perovskite solar cells. Electron. Mater. Lett. 2021, 1-11. [CrossRef]

47. Suzuki, A.; Oku, T. Effects of mixed-valence states of Eu-doped $\mathrm{FAPbI}_{3}$ perovskite crystals studied by first-principles calculation. Mater. Adv. 2021, 2, 2609-2616. [CrossRef]

48. Suzuki, A.; Oe, M.; Oku, T. Fabrication and characterization of $\mathrm{Ni}-$, $\mathrm{Co}-$, and $\mathrm{Rb}$-incorporated $\mathrm{CH}_{3} \mathrm{NH}_{3} \mathrm{PbI}_{3}$ perovskite solar cells. J. Electron. Mater. 2021, 50, 1980-1995. [CrossRef]

49. Oku, T.; Zushi, M.; Imanishi, Y.; Suzuki, A.; Suzuki, K. Microstructures and photovoltaic properties of perovskite-type $\mathrm{CH}_{3} \mathrm{NH}_{3} \mathrm{PbI}_{3}$ compounds. Appl. Phys. Express 2014, 7, 121601. [CrossRef]

50. Oku, T.; Ohishi, Y.; Ueoka, N. Highly (100)-oriented $\mathrm{CH}_{3} \mathrm{NH}_{3} \mathrm{PbI}_{3}(\mathrm{Cl})$ perovskite solar cells prepared with $\mathrm{NH}_{4} \mathrm{Cl}$ using an air blow method. RSC Adv. 2018, 8, 10389-10395. [CrossRef]

51. Taguchi, M.; Suzuki, A.; Oku, T.; Ueoka, N.; Minami, S.; Okita, M. Effects of annealing temperature on decaphenylcyclopentasilaneinserted $\mathrm{CH}_{3} \mathrm{NH}_{3} \mathrm{PbI}_{3}$ perovskite solar cells. Chem. Phys. Lett. 2019, 737, 136822. [CrossRef]

52. Oku, T.; Taguchi, M.; Kandori, S.; Suzuki, A.; Okita, M.; Minami, S.; Fukunishi, S.; Tachikawa, T. Effects of polysilane addition to chlorobenzene and high temperature annealing on $\mathrm{CH}_{3} \mathrm{NH}_{3} \mathrm{PbI}_{3}$ perovskite photovoltaic devices. Coatings 2021, 11, 665 . [CrossRef]

53. Suzuki, A.; Taguchi, M.; Oku, T.; Okita, M.; Minami, S.; Fukunishi, S.; Tachikawa, T. Additive effects of methyl ammonium bromide or formamidinium bromide in methylammonium lead iodide perovskite solar cells using decaphenylcyclopentasilane. $J$. Mater. Sci. Mater. Electron. 2021, 32, 26449-26464. [CrossRef] 
54. Ono, I.; Oku, T.; Suzuki, A.; Asakawa, Y.; Terada, S.; Okita, M.; Fukunishi, S.; Tachikawa, T. Fabrication and characterization of $\mathrm{CH}_{3} \mathrm{NH}_{3} \mathrm{PbI}_{3}$ solar cells with added guanidinium and inserted with decaphenylpentasilane. Jpn. J. Appl. Phys. 2022, 61, SB1024. [CrossRef]

55. Huang, L.; Hu, Z.; Xu, J.; Zhang, K.; Zhang, J.; Zhu, Y. Multi-step slow annealing perovskite films for high performance planar perovskite solar cells. Sol. Energy Mater. Sol. Cells 2015, 141, 377-382. [CrossRef] 